\title{
Reform and Construction of Curriculum System of Automobile Service Engineering Major
}

\author{
Peijiang Chen \\ School of Mechanical and Vehicle Engineering \\ Linyi University \\ Linyi, China \\ chenpeijiang@163.com
}

\begin{abstract}
The curriculum system is to serve the specific personnel training. The engineering majors should face the production line, make the cultivating high-quality applied talents as the goal, and construct the curriculum system. The automobile service engineering is a new engineering major. On the basis of analyzing the goal and specifications of talents cultivating, the curriculum system of the automobile service engineering is reformed and constructed from the aspects of optimizing the curriculum structure, setting the professional direction and improving the proportion of practical courses. These measures are hoped to better develop students' comprehensive ability and professional accomplishment, cultivate their innovative spirit and entrepreneurial ability and improve their employability.
\end{abstract}

Keywords-Automotive service engineering; Curriculum system; Applied talents; Professional direction

\section{INTRODUCTION}

The automobile industry is one of the pillar industries of the country and plays strong industrial leading role, representing the comprehensive development level of the national economy. At the same time, the automobile industry is also laborintensive, and it can create higher employment rate. The automobile industry has important function in promoting the economic and social development of China [1].

The automobile service industry refers to the supporting services and basic services connecting with the production and consumption in the automobile industry value chain and the extensive services of them, including automobile sales service, automobile after-sales service, automobile maintenance service, automobile beauty and decoration services, and so on. Therefore, the automotive service industry needs a diversified, hierarchical, complex and so on [2]. The automobile service industry has become a technology service industry with great development opportunities and increasing technical content. Accordingly, the automobile service industry also puts forward higher and more stringent requirements for technical personnel engaged in automobile service.

At present, with the development of China's automobile industry, the demand for high-skilled personnel increases. In order to alleviate the shortage of automobile service personnel,

This research was supported by the Teaching Quality Engineering Project of Linyi University, Shandong, China, in 2014 and 2016. the most scientific and direct way is to strengthen the training of automobile service professionals in colleges and universities, which can cultivate more suitable higher academic level of automobile service engineering professional talents to meet the development of modern automotive service industry [3-4].

Comparing with the other majors, the automobile service engineering specialty has a relatively late start and short history of development. Especially in the local colleges and universities, the experience of running schools is limited, and there is no mature experience of personnel training. All aspects of automobile service engineering are mostly in the exploration stage, and the study of innovative talents training model is necessary [5]. Since China has a vast scale of automobile service industry, it is even more important to reform and improve the curriculum system of automobile service engineering major.

Therefore, in the background of the urgent talents in automobile service field, how to cultivate a large number of innovative talents to meet the needs of the society and to set up a practical teaching system is an important topic faced by the relevant universities and educational administrators [6]. In this paper, taking Linyi University as an example, on the basis of analyzing the training objectives and training specifications of the automobile service engineering, $n$ the curriculum system is reformed and reconstructed.

\section{TRAINING OBJECTIVES AND SPECIFICATIONS OF AUTOMOBILE SERVICE ENGINEERING MAJOR}

In order to better adapt to the real situation of the rapid development of the automobile industry in Linyi, especially in the field of automobile engineering, Linyi University applied for the major of automobile service engineering in 2012 and began to recruit full-time undergraduate students in 2013

\section{A. Training Objectives}

The major is to cultivate high-quality applied talents, with comprehensive development, intellectually, physically and ethically, full of innovative spirit and entrepreneurial ability, with Yimeng spiritual characteristics and international perspective, mastering the knowledge and skills of the automobile service engineering field, receiving engineering 
practice training, having the Business ability and professional quality of analyzing and solve the professional problems, be able to do the job of marketing, testing and maintenance, finance and insurance, automobile assessment, business management in the field of automobile services.

\section{B. Training Specifications}

\section{1) Quality requirements}

Adhere to correct political direction, abide by the law, have scientific world view and positive life outlook, with a sense of social responsibility, with good professional ethics and professionalism, have teamwork spirit and collaboration ability, with scientific study attitude and pragmatic work style, with basic humanities and social science theory, with an open international perspective, with solid basic knowledge of natural science, with basic scientific thinking, mastering certain design and research methods, with engineering awareness and engineering practice ability, with innovative awareness and professional comprehensive ability, understand the development direction and application prospects of the contemporary science and technology, have good psychological quality, with healthy body and good habits, accept the necessary defense education and military training.

\section{2) Knowledge requirements}

Master the basic knowledge of management science and humanities and social sciences, such as engineering economics, management, sociology, law and environment. Master the basic principles and analyzing methods of circuit analysis, electronic technology, engineering mechanics, mechanical design, automobile structure, engine theory, automobile theory, automobile electronic control technology, automobile service system planning. Learn the knowledge and skills of 1 to 2 professional directions in the major field, master the professional knowledge of automobile marketing, automobile testing and maintenance, automobile insurance and claims, and other related automotive service engineering fields. Get better engineering practice training through professional practice course learning. Be able to use the theoretical knowledge and technical means to analyze and solve the practical problems in the field of automobile services engineering. Have good natural scientific basic knowledge and foreign language comprehensive ability. Understand the scientific knowledge of relevant areas, understanding the development trends of engineering theory and technology of the field of automobile services, understand the technical standards, industry policies, laws and regulations in the major field.

\section{3) Capacity requirements}

Be able to use the theoretical knowledge and technological means to analyze and solve the practical problems in the field of automobile service engineering, such as marketing, testing, maintenance, insurance and claims. Have the ability of scientific research, technical service, organization and management in the field of automobile service engineering. Have the ability of skilled computer and information technology application, with a strong ability of innovation and entrepreneurship. Have a certain writing power of expression with Chinese language; master a foreign language, with reading, translation professional foreign materials and literature, with strong communication skills and team spirit. Grasp the basic methods of document retrieval and materials consultation, have the ability to acquire information, expand knowledge field, continue to learn independently and improve professional skills

\section{CONSTRUCTION AND PRACTICE OF CURRICULUM SYSTEM OF AUTOMOBILE SERVICE ENGINEERING}

In order to train high quality practical talents with initiative, innovation, and practical capacities in the field of automobile service, the curriculum system of automobile service engineering is innovated and constructed.

TABLE I. The Curriculum System of the MAJor of Automobile SERvice EngineEring

\begin{tabular}{|c|c|c|c|c|c|c|c|c|c|}
\hline \multicolumn{2}{|r|}{ Course Type } & $\begin{array}{l}\text { Course } \\
\text { Nature }\end{array}$ & $\begin{array}{l}\text { Total } \\
\text { Hours }\end{array}$ & $\begin{array}{l}\text { Theory } \\
\text { Hours }\end{array}$ & $\begin{array}{r}\text { Practice } \\
\text { Hours }\end{array}$ & $\begin{array}{c}\text { Total } \\
\text { Credits }\end{array}$ & $\begin{array}{l}\text { Theory } \\
\text { Credits }\end{array}$ & $\begin{array}{r}\text { Practice } \\
\text { Credits }\end{array}$ & $\begin{array}{l}\text { Credits } \\
\text { Ratio }\end{array}$ \\
\hline \multirow{2}{*}{$\begin{array}{l}\text { General } \\
\text { Education } \\
\text { Courses }\end{array}$} & General Compulsory & Compulsory & 704 & 432 & 272 & 42 & 31 & 11 & $26.25 \%$ \\
\hline & General Elective & Elective & 192 & 192 & 0 & 12 & 12 & 0 & $7.50 \%$ \\
\hline \multirow{3}{*}{$\begin{array}{l}\text { Professional } \\
\text { Education } \\
\text { Courses }\end{array}$} & Professional Basic & Compulsory & 432 & 384 & 48 & 25.5 & 24 & 1.5 & $15.94 \%$ \\
\hline & Professional Compulsory & Compulsory & 552 & 458 & 94 & 30.5 & 27.5 & 3 & $19.06 \%$ \\
\hline & Professional Elective & Elective & 304 & 200 & 104 & 16 & 12.5 & 3.5 & $10 \%$ \\
\hline \multicolumn{2}{|r|}{ Practice Courses } & Compulsory & $33 \mathrm{~W}$ & 0 & $33 \mathrm{~W}$ & 34 & 0 & 34 & $21.25 \%$ \\
\hline \multicolumn{2}{|r|}{ Total } & & $\begin{array}{c}2184 \\
+33 \mathrm{~W}\end{array}$ & 1666 & $\begin{array}{r}518 \\
+33 \mathrm{~W}\end{array}$ & 160 & 107 & 53 & $100 \%$ \\
\hline \multicolumn{2}{|r|}{ Explanation } & \multicolumn{8}{|c|}{$\begin{array}{l}\text { The credits of the practice courses occupies } 33.13 \% \\
\text { Note: The percentage of practice credits is as follows: (computer credits }+ \text { experimental credits }+ \\
\text { other in-class practice credits }+ \text { intensive practice credits) / total credits } \times 100 \% \text {. }\end{array}$} \\
\hline
\end{tabular}




\section{A. Optimize the Course Structure, Build an Application-} based Curriculum System

The major of automobile service engineering in Linyi Universities is to cultivate high quality practical talents being competent for a certain automobile service jobs, the curriculum system should be constructed focusing on the first-line production of the automobile service industry. On the basis of consolidating the theoretical basis and enhancing the sustainable development of students, the major should strengthen the effort in personnel training with professional ability, job capacity, comprehensive ability and innovation, entrepreneurial ability.

Since the automobile service engineering major involves many disciplines and wide fields, the theoretical course should focus on strengthening basic knowledge learning and quality education, the practical courses should focus on strengthening students' practical ability and comprehensive knowledge ability. The personnel training must update the course content, optimize the curriculum structure, combine the theoretical courses and practical courses organically, and build the application-based curriculum system to meet the requirements of automobile service engineering fields. The curriculum system of the automobile service engineering major is given, as shown in Table 1.

\section{B. Strengthen the Modular Teaching System, Set Major Directional Courses}

The modular teaching system is an effective way to carry out engineering education and quality education for contemporary college students. Strengthening the construction of modular teaching system in automobile service engineering can effectively improve the innovation ability and practical ability of college students. In order to better highlight the advantages of modular teaching system, the elective courses should be gradually increased in the curriculum system. Combined with the characteristics of students, different elective courses are set to stimulate college students' strong desire for knowledge and develop students' personality features.

Based on the school general courses, professional basic courses and professional compulsory courses, according to industry development and regional requirements, the curriculum modules of different professional development directions are set. The students can select them based on their career planning to facilitate the expansion of student career, meet to the needs of students personalized learning, achieve the diversification of personnel training. The automobile service engineering major has two directions, as shown in Table 2.

\section{Improve the Proportion of Practical Courses, Build a Hierarchical Practice Teaching System}

The practical teaching is an important part of cultivating applied talents. Whether automobile production services, automobile testing services, automobile maintenance services, or automobile marketing, automobile insurance claims, it requires strong practical ability. Therefore, the professional courses should focus on the application of knowledge, the cultivating of engineering and technical ability, and the enhancement of practical ability. The proportion of training courses should be increased appropriately. On the basis of the improvement of the experimental class hours, the centralized practice teaching is arranged continually from the second semester. These practical courses include metalworking, vehicle disassembly training, automobile driving practice, automobile maintenance and maintenance training, automobile marketing services training, automobile service basic skills training. These courses are employment-oriented, aiming at the development needs of enterprises, and building students' professional skills.

TABLE II. ThE SET OF PROFESSIONAL DiRECTION OF AUTOMOBILE SERVICE ENGINEERING

\begin{tabular}{|l|l|}
\hline \multicolumn{1}{|c|}{$\begin{array}{c}\text { Professional } \\
\text { Direction }\end{array}$} & \multicolumn{1}{c|}{ Courses } \\
\hline $\begin{array}{l}\text { Direction of } \\
\text { Automobile' } \\
\text { Technical } \\
\text { Service }\end{array}$ & $\begin{array}{l}\text { Automobile Testing and Diagnostic Technology } \\
\text { Automobile Maintenance Technology } \\
\text { Second Hand Automobile Identification and } \\
\text { Assessment } \\
\text { Automobile Insurance and Claims }\end{array}$ \\
\hline $\begin{array}{l}\text { Automobile } \\
\text { Service } \\
\text { and Management }\end{array}$ & $\begin{array}{l}\text { Automobile Market } \\
\text { Automobile Electronic Commerce } \\
\text { Automobile Consumer Psychology }\end{array}$ \\
\hline
\end{tabular}

In the practice of hierarchical practical teaching system, the practice teaching methods and means are reformed [7-8]. In order to meet the characteristics of the professional teaching of automobile service engineering, the multimedia professional laboratories are established. The laboratories multi-functional comprehensive teaching sites which combine theoretical teaching and experimental teaching, with the characteristics of automobile service engineering, a variety of teaching methods and a variety of teaching forms [9-10]. The college continues to strengthen cooperation with industry, enterprises and scientific research units, signs a number of off-campus cooperation units and establishes of a number of off-campus practice bases. The enterprises provide internship places for students, the university provides technical support for enterprises. The students have more practical hands-on opportunities, all students can consolidate the knowledge, improve operational skills, accumulate experience to solve practical problems.

\section{CONCLUSIONS}

With the popularization of the automobile, the automobile service industry is in urgent need of a large number of the high quality of the applied talents. The professional training of automobile service engineering should be connected with the social needs, which is system engineering. It is a major issue placed in front of higher education workers and is also the direction of teaching reform and development of automobile service engineering in colleges and universities.

Aiming at cultivating students' innovative spirit and entrepreneurial ability, from the aspects of optimizing the curriculum structure, setting the professional direction and 
improving the proportion of practical courses, the professional curriculum system of automobile service engineering major are reformed and constructed.

It should be noted that the reform of the curriculum system inevitably leads to changes in teaching methods. How to improve the teaching methods under the new curriculum structure, the combination of practices inside and outside of campus, and other related issues need further study.

\section{ACKNOWLEDGMENT}

This research was supported by the Teaching Quality Engineering Project of Linyi University, Shandong, China, in 2014 and 2016.

\section{REFERENCES}

[1] Y. Sun, and L. Zhang, "The Construction of Practical Teaching System of Automobile Service Engineering in Vocational and Technical Teachers Colleges," Journal of Jilin Teachers Institute of Engineering and Technology, vol. 31, no. 2, pp. 42-44, February 2015.

[2] P, Li, "Construction of Curriculum System on Automotive Service Engineering in Application-oriented Institutions" Journal of Xichang College. Natural Science Edition, vol. 25, no. 3, pp. 126-128, September 2011.
[3] S. Xiao, Z. Deng, and Q. Hu, "Research on Training Pattern of Applied Talents about Automobile Service Engineering in College," China Modern Educational Equipment, no. 19, pp. 49-50, October 2011.

[4] P. Chen, "Study and Practice of Entrepreneurial Talent Training Model in Automotive Service Field," Advances in Social Science, Education and Humanities Research, vol. 69, pp. 983-986, July 2016.

[5] X. Ning, J. Yao, Y. Wang, and X. Chen, "On the Construction of Talents Training Mode of Automobile Service Engineering Specialty," Journal of Henan Institute of Science and Technology, vol. 6, pp. 3032, June 2015.

[6] Q. Ma, Y. Luo, Y. Wang, and H. Ren, "The Architecture and Construction of a Practice Teaching Platform for the Automobile Service Engineering Major,” vol. 31, no. 8, pp. 107-110, August 2012.

[7] J. Liu, "Establish and Perfect the "Automobile Service Engineering Practice Teaching System" Strengthening the Cultivation of College Students' Vocational Ability - Building Professional Training System of Experiment about the Automobile Service Engineering Specialty in Guiyang University," Journal of Guiyang College (Nature Sciences), vol. 11 , no. 2, pp. 80-83, June 2016.

[8] X. Mi, and P. Chen, "Research on Project Teaching of the Course Automobile Electronic and Electrical Equipment," Advances in Computer Science Research, vol. 25, pp. 528-531, September 2015.

[9] N. Sang, and Y. Bai, "Overall Optimization of Automobile Service Engineering Core Curriculum System," Journal of Changzhou Institute of Technology, vol. 27, no. 1, pp. 85-89, February 2014.

[10] P. Chen, "Study on the Modes of Resource Integration and Utilization of Foreign Schools and Enterprises," Education Management and Management Science, vol. 7, pp. 265 -268, July 2015. 